\title{
Leptin regulates the proliferation and apoptosis of human endometrial epithelial cells
}

\author{
TETSUJI TANAKA and NAOHIKO UMESAKI \\ Department of Obstetrics and Gynecology, Wakayama Medical \\ University, 811-1 Kimi-idera, Wakayama 641-0012, Japan
}

Received June 27, 2008; Accepted August 22, 2008

DOI: 10.3892/ijmm_00000073

\begin{abstract}
The biological functions of leptin in the human endometrial epithelium were investigated using the human endometrial epithelial cell line, HHUA. Specifically, the effects of leptin on the proliferation and apoptosis of HHUA cells induced by treatment with anti-Fas IgM or anticancer drugs were examined. RT-PCR detected the expression of four leptin receptor isoform mRNAs in the cells and flow cytometric analysis revealed cell surface expression of the leptin receptor molecules. Leptin stimulated HHUA cell proliferation in a dose-dependent manner at concentrations below the normal serum leptin level. Leptin enhanced antiFas IgM-mediated growth inhibition and DNA fragmentation, but did not enhance the expression of either Fas antigen or Fas ligand. Moreover, leptin had no effect on anticancer drug-induced apoptosis. Based on these results, leptin at a physiological serum concentration, may regulate the remodeling of the human endometrial epithelium by stimulating cell proliferation and enhancing the Fas-specific intracellular apoptotic signaling pathway.
\end{abstract}

\section{Introduction}

Leptin, the product of the OB gene, is a $16-\mathrm{kDa}$ nonglycosylated polypeptide that is mainly synthesized by adipocytes and released into the bloodstream. Subsequently, it interacts with leptin receptors on various cells around the body and regulates energy balance and body weight. Previously, six different leptin receptor isoforms, which are generated by mRNA alternative splicing, were identified (1-4). The six isoforms have the same extracellular domain, which is homologous to the class I cytokine receptor family (3), but differ in their intracellular domains. OBRL, the long-form receptor, and three OBRS short-form receptors (OBRS-

Correspondence to: Dr Tetsuji Tanaka, Department of Obstetrics and Gynecology, Wakayama Medical University, 811-1 Kimi-idera, Wakayama 641-0012, Japan

E-mail: obgywmu@wakayama-med.ac.jp

Key words: leptin, Fas, apoptosis, endometrium, epithelium
B219.1, OBRS-B219.2 and OBRS-B219.3) are the major isoforms present on mammalian cells. OBRL contains an intact intracellular domain and directly activates intracellular signal transduction, especially by the activation of the STAT3 pathway, upon ligand binding $(3,5,6)$. In contrast, the OBRS isoforms, which contain truncated intracellular domains and are unable to activate the STAT3 pathway (3), may transduce signals via the activation of JAK2, IRS-1 or MAPK (7).

The leptin and leptin receptor expression profiles in the female reproductive system have been investigated. Western blot analysis revealed OBRL protein expression in the glandular and luminal epithelium of the human endometrium $(8,9)$ as well as in cultured human endometrial epithelial cells (8). Recent studies have indicated that leptin may play a role in reproductive phenomena such as menstruation, ovarian follicular development, embryo implantation, embryo development, pregnancy maintenance and parturition (10-12). In particular, the leptin-leptin receptor system may play an important role in embryo implantation based on evidence that leptin stimulates early embryo development (13-15), leptin receptors are highly expressed at implantation sites in the endometrium $(8,9,15-19)$ and specific inhibition of leptin inhibits embryo implantation (20). Furthermore, menstrual cycle-dependent cyclic expression of leptin receptors in the endometrium, where the embryo becomes implanted, has also been reported $(8,9,15-19)$, and there are several reports that embryos produce leptin $(13,21,22)$.

Fas-mediated apoptosis is considered to affect embryo implantation, since Fas antigen, an apoptotic receptor, is expressed in the pre-implantation human endometrial epithelium (23-25) and endometrial epithelial apoptosis occurs during embryo implantation $(26,27)$. Moreover, specific stimulation of Fas antigen induces apoptosis of normal human endometrial epithelial cells $(25,28,29)$. However, specific Fas-mediated signaling was reported to stimulate the proliferation and survival of normal human endometrial stromal cells, rather than their apoptosis, despite the expression of Fas antigen on the cell surface (31).

With the exception of embryo implantation, the biological functions and roles of leptin in the human endometrium in vivo have not yet been clarified. Leptin is localized in the endometrium throughout the menstrual cycle, rather than only during the implantation period, suggesting that it may have other biological functions. Therefore, we investigated the effects of leptin on the proliferation and viability of human 
endometrial epithelial cells using an endometrial epithelial cell line. We selected the HHUA human endometrial epithelial cell line for this study because the cells express high levels of Fas antigen as well as functional estrogen receptors and progesterone receptors, similar to normal human endometrial epithelium (32), and form glandular luminal structures in collagen gel cultures, similar to the structures of normal glandular epithelial cells (33). In addition, we performed a karyotyping analysis of 20 HHUA cells and detected normal 46XX karyotypes (data not shown). Furthermore, HHUA cells express functional Fas antigens on the cell surfaces that mediate specific apoptotic signals (28). Based on these characteristics, HHUA cells are considered to retain many of the intracellular signaling pathways found in normal endometrial epithelial cells. Hence, we used HHUA cells to examine the expression of leptin receptor isoforms and the effects of leptin on basic cellular functions, such as proliferation, viability and apoptosis.

\section{Materials and methods}

Cell line and cell culture. The HHUA cell line was obtained from Riken Cell Bank (Tsukuba, Japan). The cells were cultured in OPTI-MEM (Invitrogen Corp., Carlsbad, CA) supplemented with $5 \%$ fetal calf serum (FCS, Equitech Bio Inc., Ingram, TX), $100 \mathrm{U} / \mathrm{ml}$ penicillin (PC, Invitrogen) and $100 \mu \mathrm{g} / \mathrm{ml}$ streptomycin (SM, Invitrogen).

Cell viability assay. Cell viability was examined using the cell proliferation assay kit (Dojin, Tokyo, Japan). The stimulatory effects of mouse anti-human Fas monoclonal IgM (clone CH-11, MBL, Nogoya, Japan), leptin and anticancer drugs on the growth of HHUA cells were assayed as follows. On day 1, HHUA cells in the log phase were detached using $0.25 \%$ trypsin/1 mM EDTA (Invitrogen) and cultured overnight in 96-well plates (5000 cells/well) in OPTI-MEM/5\% FCS/PC/SM. On day 2, combinations of anti-Fas IgM, recombinant human leptin (PeproTech EC Ltd., London, UK), recombinant human tumor necrosis factor (TNF- $\alpha$ ) (Genzyme, Cambridge, MA) and/or anticancer drugs were added to the cells. On day 4, the viable cell numbers were counted using the kit. The anticancer drugs were kind gifts from pharmaceutical companies. SN38, a major active metabolite of irinotecan-HCl (CPT-11), was obtained from Yakult Co. Ltd. (Tokyo, Japan). Paclitaxel and cisplatin (CDDP) were provided by Nihon-Kayaku Co. (Tokyo, Japan). Nedaplatin (NPL) was obtained from Shionogi Co. Ltd. (Osaka, Japan).

DNA fragmentation assay. HHUA cells in the log phase were detached with $0.25 \%$ trypsin $/ 1 \mathrm{mM}$ EDTA and cultured overnight in OPTI-MEM/5\% FCS/PC/SM ( $3 \times 10^{6}$ cells/dish). On day 3 , recombinant human leptin (final concentration, $200 \mathrm{ng} / \mathrm{ml}$ ) was added to the cells for $1 \mathrm{~h}$, followed by the addition of anti-Fas IgM (final concentration, $75 \mathrm{ng} / \mathrm{ml}$ ). On day 4 , genomic DNA was extracted from all cells, including dead cells, using a SepaGene DNA extraction kit (SankyoJunyaku Co. Ltd., Tokyo, Japan) and treated with $100 \mu \mathrm{g} / \mathrm{ml}$ of RNase A (Sigma, St. Louis, MO) in TE buffer (10 mM Tris $\mathrm{pH} 8.0,2 \mathrm{mM}$ EDTA) for $90 \mathrm{~min}$ at $37^{\circ} \mathrm{C}$ to remove any contaminating RNA. Then, $\sim 20 \mu \mathrm{g}$ of the genomic DNA was electrophoresed in a $1.2 \%$ agarose gel at $50 \mathrm{~V}$ for $\sim 2 \mathrm{~h}$, stained with $5 \mu \mathrm{g} / \mathrm{ml}$ ethidium bromide and visualized by $\mathrm{UV}$ illumination.

Reverse transcriptase-polymerase chain reaction ( $R T-P C R)$. Total RNA was isolated from cultured cells using TRIzol reagent (Invitrogen) and subjected to RT-PCR. Aliquots containing $1 \mu \mathrm{g}$ of total RNA were pretreated with DNase I (Invitrogen) and used as a template for cDNA synthesis by reverse transcriptase (Bio-Rad, Hercules, CA) in a reaction volume of $20 \mu 1$. Each cDNA product was diluted to $100 \mu 1$. The PCR reaction mixture $(25 \mu \mathrm{l})$ contained $5 \mu \mathrm{l}$ of diluted cDNA, $0.125 \mu 1$ of Hotstart polymerase (Qiagen Inc., Valencia, CA), $0.2 \mathrm{mM}$ dNTP, $1 \mathrm{xQ}$ solution and $0.5 \mu \mathrm{M}$ primers. The primers used for OBRL (34), OBRS-B219.1, OBRS-B219.2 and OBRS-B219.3 (35) are summarized in Table I. We purchased synthesized PCR primers from Yashima Co. (Osaka, Japan). The PCR protocols were slightly modified from previously reported methods $(34,35)$. Briefly, an initial hot start at $95^{\circ} \mathrm{C}$ for 15 min was followed by 30-36 amplification cycles $\left(60 \mathrm{sec}\right.$ at $94^{\circ} \mathrm{C}, 60 \mathrm{sec}$ at the annealing temperature and $60 \mathrm{sec}$ at $72^{\circ} \mathrm{C}$ ). The annealing temperatures are shown in Table I. The PCR products were electrophoresed in 1.5-2.0\% agarose gels at $100 \mathrm{~V}$ for $\sim 30-40 \mathrm{~min}$ and visualized by staining with $5 \mu \mathrm{g} / \mathrm{ml}$ ethidium bromide.

Semiquantitative flow cytometry. HHUA cells were detached and re-cultured in dishes. Untreated HHUA cells and HHUA cells treated with leptin (final concentration, $200 \mathrm{ng} / \mathrm{ml}$ ) for 2 days were detached from the dishes using $3 \mathrm{mM}$ EDTA in phosphate-buffered saline (PBS), and stained according to the following procedure. Cells $\left(3 \times 10^{5}\right)$ were incubated with an excess of one of the primary antibodies for $20 \mathrm{~min}$ at $4^{\circ} \mathrm{C}$, washed twice with washing buffer (PBS containing 2\% FCS and $0.1 \% \mathrm{NaN}_{3}$ ) and incubated with a secondary antibody [FITC-conjugated goat anti-mouse IgG $(\mathrm{H}+\mathrm{L})$; Dako-Japan, Kyoto, Japan] for $20 \mathrm{~min}$ at $4^{\circ} \mathrm{C}$. After two washes, the cells were suspended in $200 \mu \mathrm{l}$ of the washing buffer and analyzed with a FACScalibur ${ }^{\mathrm{TM}}$ (Becton Dickinson, Mountain View, CA). The primary antibodies used were: mouse anti-human leptin receptor monoclonal antibody (clone 52208, R\&D Systems Inc., Minneapolis, MO); mouse anti-human Fas (CD95) monoclonal antibody (clone UB2, MBL); and mouse anti-human Fas ligand (CD178) monoclonal antibody (clone NOK-1, BD Biosciences, San Jose, CA).

\section{Results}

The expression of four OBR mRNA isoforms in HHUA cells was examined by RT-PCR. As shown in Fig. 1A, all four isoform mRNAs were detected in the cells. Flow cytometric analysis revealed that the leptin receptor molecules were expressed on the HHUA cell surface (Fig. 1B).

The functions of leptin receptors on endometrial epithelial cells were investigated by examining the effects of leptin on HHUA cells. As shown in Fig. 2A, leptin stimulated the proliferation of HHUA cells in a dose-dependent manner. Furthermore, leptin stimulated the proliferation of HHUA cells at concentrations above the normal serum leptin 
Table I. Primer sequences, length of amplified templates and cycle conditions for RT-PCR.

\begin{tabular}{|c|c|c|c|c|c|}
\hline Gene product & & Primer sequence $5^{\prime}-3^{\prime}$ & $\begin{array}{c}\text { Product } \\
\text { length (bp) }\end{array}$ & $\begin{array}{l}\text { No. of } \\
\text { cycles }\end{array}$ & $\begin{array}{l}\text { Annealing } \\
\text { temp. }\left({ }^{\circ} \mathrm{C}\right)\end{array}$ \\
\hline OBRL & $\begin{array}{l}\text { up } \\
\text { down }\end{array}$ & $\begin{array}{l}\text { TTGTGCCAGTAATTATTTCCTCTT } \\
\text { CTGATCAGCGTGGCGTATTT }\end{array}$ & 439 & 30 & 58 \\
\hline OBRS-B219.1 & $\begin{array}{l}\text { up } \\
\text { down }\end{array}$ & $\begin{array}{l}\text { TTGGAAGCCCCTGATGAAA } \\
\text { AGCAGATAAACAAGTGAACAAAG }\end{array}$ & 822 & 36 & 56 \\
\hline OBRS-B219.2 & $\begin{array}{l}\text { up } \\
\text { down }\end{array}$ & $\begin{array}{l}\text { TTGGAAGCCCCTGATGAAA } \\
\text { AGGTGCGCACGAGGTAGGA }\end{array}$ & 772 & 36 & 62 \\
\hline OBRS-B219.3 & $\begin{array}{l}\text { up } \\
\text { down }\end{array}$ & $\begin{array}{l}\text { ATTCAATTGGTGCTTCTGTT } \\
\text { CATTGGGTTCATCTGTAGTG }\end{array}$ & 573 & 36 & 56 \\
\hline
\end{tabular}

concentration (36-39) (Fig. 2A, arrow), indicating that the normal serum level of leptin may stimulate the proliferation of endometrial epithelial cells in vivo.

HHUA cells express Fas antigen on the cell surface, similar to normal endometrial epithelial cells (28). As reported previously (28), anti-Fas IgM inhibited the viability of HHUA cells (Fig. 2B) and induced DNA fragmentation (Fig. 2C) in dose-dependent manners. Leptin significantly enhanced the anti-Fas IgM-induced growth inhibition (Fig. 2B) and DNA fragmentation (Fig. 2C) of HHUA cells.

To further investigate the leptin-induced enhancement of Fas-mediated apoptosis, quantitative flow cytometric analyses were performed. As shown in Fig. 3, leptin did not stimulate the expression of either Fas antigen or Fas ligand in HHUA cells. The effects of leptin on anticancer drug-induced apoptosis of HHUA cells were examined. As shown in Fig. 4, leptin enhanced Fas-mediated apoptosis, but not the apoptosis induced by four anticancer drugs, namely CDDP, NPL, paclitaxel and SN38. TNF- $\alpha$ did not inhibit the growth of HHUA cells, since the cells expressed low levels of TNF receptors (data not shown).

\section{Discussion}

Although binding of leptin to the human endometrial epithelium has been reported $(8,9,16)$, the functions of endometrial leptin have not been clarified. In the present study, we examined the effects of leptin on the human endometrial epithelial cell line HHUA. The cells expressed all four leptin receptor isoform mRNAs examined and exhibited cell surface expression of the leptin receptor molecules. Leptin stimulated the proliferation of HHUA cells in a dosedependent manner. Notably, at concentrations corresponding to $\leq 30 \%$ of the normal serum leptin level (36-39), leptin significantly stimulated HHUA cell proliferation. Similar to normal human endometrial epithelial cells, HHUA cells possess functional estrogen receptors and progesterone receptors, and express functional Fas antigen through which Fas-mediated apoptosis can be induced (28). The present study revealed that the normal serum level of leptin enhanced Fas-mediated apoptosis of HHUA cells. Notably, leptin did not exhibit any effects on the apoptosis induced by anticancer drugs. This is the first demonstration that leptin can stimulate

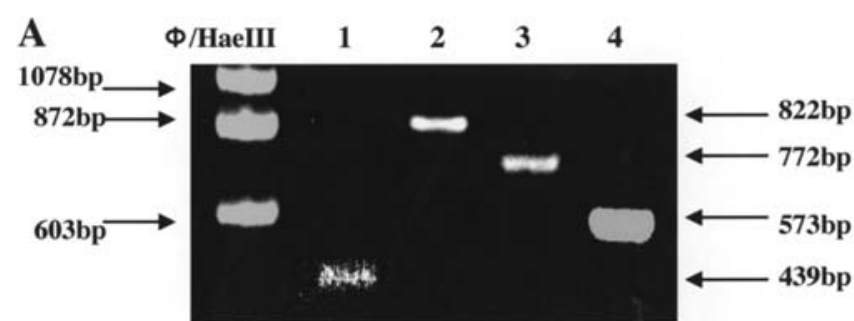

1; OBRL, 2; OBRS-B219.1, 3; OBRS-B219.2, 4; OBRS-B219.3

B

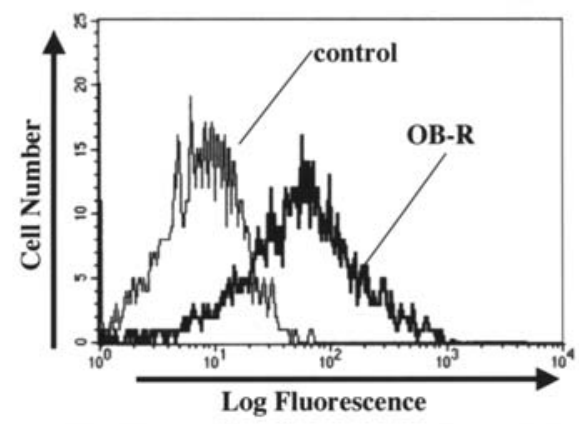

Figure 1. Expression of leptin receptor isoforms in HHUA cells. (A) Expression of leptin receptor isoform mRNAs in HHUA cells. (B) Cell surface expression of leptin receptors in HHUA cells.

endometrial epithelial cell proliferation and specifically enhance Fas-mediated apoptosis of human endometrial epithelial cells.

Although several studies have shown that leptin receptors are expressed in the human endometrial epithelium, few reports have demonstrated that eutopic human endometrial epithelium produces leptin. Although embryos were reported to produce leptin $(13,22)$, the production level are very low. Since the presence of endometrial epithelial leptin has mainly been investigated in non-pregnant endometrial tissues $(8,9,16-$ 19), it is possible that endometrial leptin is derived from serum and/or peritoneal leptin. However, it is possible that eutopic endometrial tissues may produce leptin under certain conditions, since leptin production by endometriotic tissue has been reported (19).

One of the important physiological roles of leptin in the human endometrium must involve strong stimulation of 


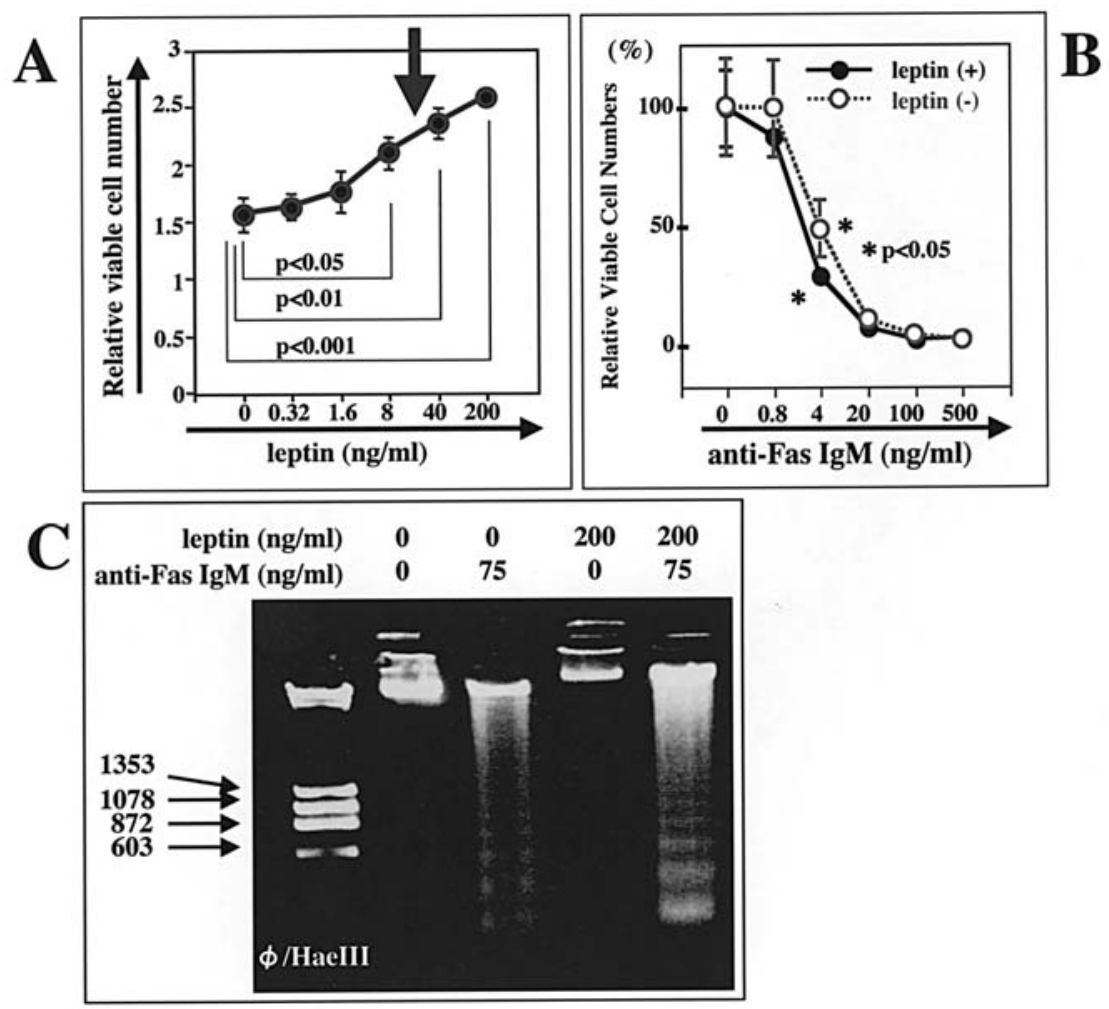

Figure 2. Effects of leptin on the proliferation and Fas-mediated apoptosis of HHUA cells. (A) Leptin stimulates HHUA cell proliferation in a dose-dependent manner. The arrow indicates the normal serum leptin concentration. (B) Leptin enhances Fas-mediated growth inhibition of HHUA cells. The cells were pretreated with leptin at a final concentration of $50 \mathrm{ng} / \mathrm{ml}$. The solid line with closed circles shows the combined effects of leptin and anti-Fas IgM. The dotted line with open circles shows the effects of anti-Fas IgM without leptin. (C) Leptin enhances Fas-mediated DNA fragmentation in HHUA cells. In this experiment, the cells were pretreated with leptin at a final concentration of $200 \mathrm{ng} / \mathrm{ml}$ for $1 \mathrm{~h}$, and then stimulated with anti-Fas IgM at a final concentration of $75 \mathrm{ng} / \mathrm{ml}$.

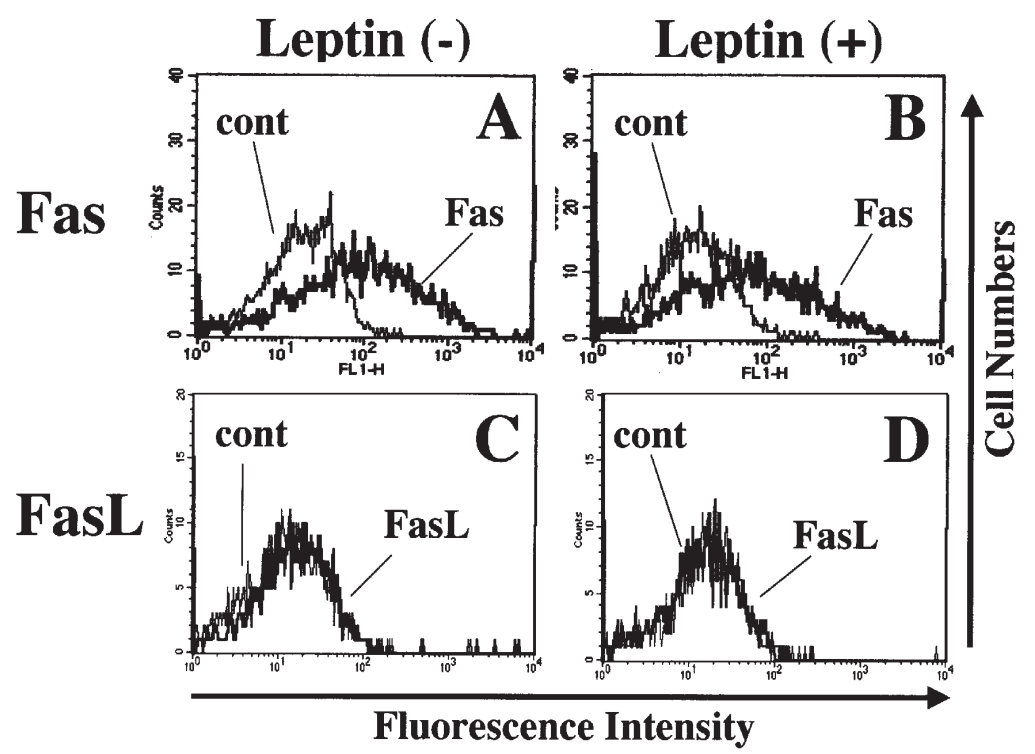

Figure 3. Effects of leptin on the cell surface expression levels of Fas antigen and Fas ligand in HHUA cells. The thick lines show the expression levels of Fas or Fas ligand (FasL) while the thin lines are negative controls. (A and C) Cells with no leptin. (B and D) Cells treated with leptin at a final concentration of $200 \mathrm{ng} / \mathrm{ml}$. No significant differences in Fas expression were observed after leptin stimulation (A vs. B). Leptin treatment did not induce Fas ligand expression (C vs. D).

endometrial epithelial cell proliferation, since the growth of HHUA cells was significantly and dose-dependently stimulated by leptin at concentrations corresponding to $\leq 30 \%$ of the normal serum leptin level. No significant differences were detected in the serum leptin levels between endometriotic patients and non-endometriotic women, whereas the peritoneal leptin levels were significantly higher in endometriotic patients than in non-endometriotic women $(36,38,40-42)$. Hence, the larger amount of peritoneal leptin in endometriotic women may stimulate endometrial epithelial cells in the menstrual 

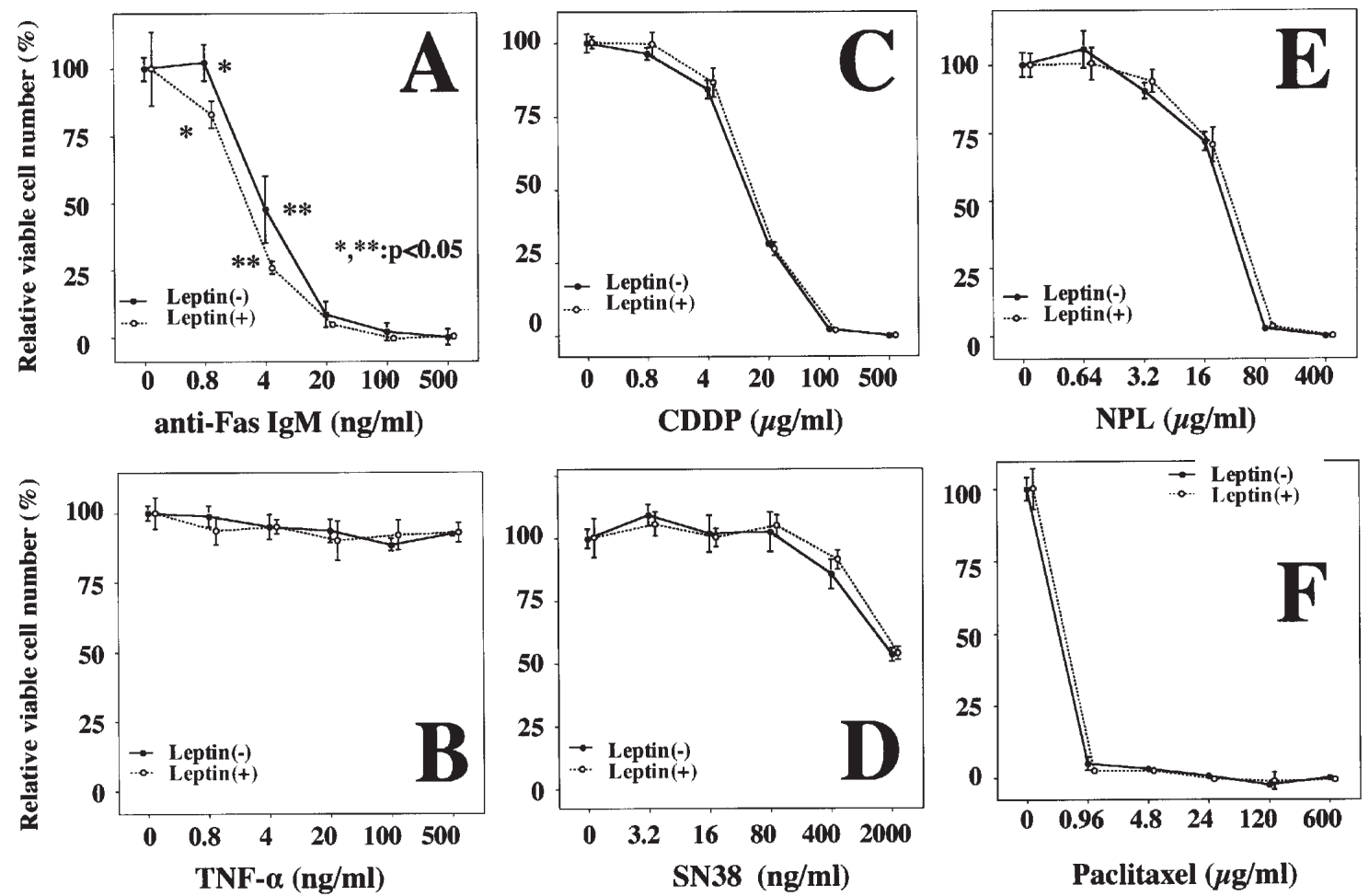

Figure 4. Effects of leptin on anticancer drug-induced apoptosis. (A) Leptin enhances the Fas-mediated growth inhibition of HHUA cells. In this experiment, leptin, at a final concentration of $100 \mathrm{ng} / \mathrm{ml}$, was added. The dotted lines with open circles show the combined effects of leptin and anticancer drugs while the solid lines with closed circles show the effects of the anticancer drugs without leptin. The leptin combination effects on the growth inhibition by TNF- $\alpha$ (B), CDDP (C), SN38 (D), NPL (E) or paclitaxel (F).

blood flowing into the peritoneal cavity from the endometrium to proliferate and become implanted into the peritoneum. Since leptin inhibits the differentiation of normal human endometrial stromal cells and stimulates their viability (31), the increased levels of peritoneal leptin in endometriotic patients may stimulate the viability and inhibit the differentiation of endometrial stromal cells in menstrual blood arising from the eutopic endometrium, and thereby induce peritoneal implantation of endometrial tissues.

In the present study, leptin was found to enhance Fasmediated apoptosis of HHUA cells. Since leptin did not enhance either Fas or Fas ligand expression in HHUA cells, leptin is considered to enhance the intracellular apoptotic signals after Fas activation. Fas antigen is a well-known death receptor that is widely distributed and expressed in the majority of cells in the human body. Stimulation with antiFas IgM acts in a similar manner to Fas ligand stimulation, and tends to induce the apoptosis of most Fas-expressing cells. As an exception, anti-Fas IgM treatment stimulates the viability of normal human endometrial stromal cells, rather than their apoptosis, although endometrial stromal cells express moderate levels of Fas antigen on their cell surface (30). Leptin also enhances the viability of normal human endometrial stromal cells, similar to the case for anti-Fas $\operatorname{IgM}$ (31). These findings indicate that leptin may enhance post-receptor intracellular signaling after Fas stimulation, depending on whether Fas antigen mediates apoptotic or survival signals.

It was notable that leptin had no effects on anticancer drug-induced apoptosis, but enhanced Fas-mediated apoptosis.
These observations suggest that leptin enhances intracellular apoptotic signaling after Fas antigen stimulation and that the signals after Fas are distinct from the apoptotic intracellular signals induced by anticancer drug treatment. Therefore, leptin may play a physiological role in enhancing Fas-specific intracellular signaling pathways in endometrial epithelial cells.

The present study revealed that leptin enhanced Fasmediated apoptosis of the HHUA human endometrial epithelial cell line. There have been several reports showing that leptin enhances apoptosis in various cell lineages, including adipocytes (43-45), rat intestinal mucosal (46), human bone marrow stromal (47) and ovarian granulosa cells $(48,49)$. In contrast, there are also several reports that leptin inhibits apoptosis and enhances the survival of various cell lineages, including pancreatic islet cells $(50)$, lymphocytes $(51,52)$, monocytes (53), neutrophils (54), eosinophils (55), dendritic (56), neuroblastoma (57) and esophageal carcinoma cells (58), embryos (59) and normal human endometrial stromal cells (31). The anti-apoptotic effects of leptin are reportedly mediated by p42/44 MAP kinase activation signals (53), STAT3 activation pathways (60) or NFKB activation signals (61). However, it is possible that the intracellular signals induced by leptin stimulation vary in different cell lineages. As several reports have shown that leukemia inhibitory factor (LIF) has similar biological effects on apoptosis and survival in the same cell lineages affected by leptin $(20,62,63)$, STAT3 activation pathways common to leptin stimulation and LIF stimulation must be involved in these phenomena at the first step. Recently, six different leptin receptor isoforms 
have been identified and are considered to mediate different intracellular signals. We have demonstrated that HHUA cells expressed at least four of these receptor isoforms, and the expression levels of the individual leptin receptor isoforms are likely to differ among cell lineages. These different expression ratios of receptor isoforms may represent one of the reasons why leptin enhances the apoptosis of some cells and the survival of others.

The present study demonstrated novel functions of leptin at physiological serum leptin levels, namely stimulation of endometrial epithelial cell proliferation and enhancement of Fas-specific apoptosis of endometrial epithelial cells. Since menstrual blood contains a large amount of leptin, leptin may stimulate endometrial regeneration after endometrial shedding. Furthermore, leptin may repair the endometrial epithelium after embryo implantation. In endometriotic patients, increased peritoneal leptin may lead to implantation of endometrial cells from the eutopic endometrium into the peritoneum or stimulate the proliferation of peritoneal endometriotic cells. Embryo-derived leptin may enhance epithelial apoptosis for successful implantation, since leptin receptor expression, Fas expression and epithelial apoptosis have been reported to increase during the implantation period. Thus, leptin has important physiological roles in reproduction.

\section{Acknowledgements}

This study was supported in part by a Grant-in-aid for scientific research from the Ministry of Education, Science, Sports and Culture of Japan.

\section{References}

1. Lee GH, Proenca R, Montez JM, et al: Abnormal splicing of the leptin receptor in diabetic mice. Nature 379: 632-635, 1996.

2. Takaya K, Ogawa Y, Isse N, et al: Molecular cloning of rat leptin receptor isoform complementary DNAs - identification of a missense mutation in Zucker fatty $(\mathrm{fa} / \mathrm{fa})$ rats. Biochem Biophys Res Commun 225: 75-83, 1996.

3. Tartaglia LA: The leptin receptor. J Biol Chem 272: 6093-6096, 1997.

4. Barr VA, Lane K and Taylor SI: Subcellular localization and internalization of the four human leptin receptor isoforms. J Biol Chem 274: 21416-21424, 1999.

5. Baumann H, Morella KK, White DW, et al: The full length leptin receptor has signaling capabilities of interleukin 6-type cytokine receptors. Proc Natl Acad Sci USA 93: 8734-8738, 1996.

6. Vaisse C, Halaas JL, Horvath CM, et al: Leptin activation of Stat 3 in the hypothalamus of wild-type and $o b / o b$ mice but not $d b / d b$ mice. Nat Genet 14: 95-97, 1996.

7. Bjorbaek C, Uotani S, da Silva B, et al: Divergent signaling capacities of the long and short isoforms of the leptin receptor. $J$ Biol Chem 272: 32686-32695, 1997.

8. Kitawaki J, Koshiba H, Ishihara H, et al: Expression of leptin receptor in human endometrium and fluctuation during the menstrual cycle. J Clin Endocrinol Metab 85: 1946-1950, 2000.

9. Gonzalez RR, Caballero-Campo P, Jasper M, et al: Leptin and leptin receptor are expressed in the human endometrium and endometrial leptin secretion is regulated by the human blastocyst. J Clin Endocrinol Metab 85: 4883-4888, 2000.

10. Gonzalez RR, Simon C, Caballero-Campo P, et al: Leptin and reproduction. Hum Reprod Update 6: 290-300, 2000.

11. Malik NM, Carter ND, Murray JF, et al: Leptin requirement for conception, implantation, and gestation in the mouse. Endocrinology 142: 5198-5202, 2001.

12. Cervero A, Horcajadas JA, Dominguez F, et al: Leptin system in embryo development and implantation: a protein in search of a function. Reprod Biomed Online 10: 217-223, 2005.
13. Kawamura K, Sato N, Fukuda J, et al: Leptin promotes the development of mouse preimplantation embryos in vitro. Endocrinology 143: 1922-1931, 2002.

14. Craig JA, Zhu H, Dyce PW, et al: Leptin enhances porcine preimplantation embryo development in vitro. Mol Cell Endocrinol 229: 141-147, 2005.

15. Yang YJ, Cao YJ, Bo SM, et al: Leptin-directed embryo implantation: leptin regulates adhesion and outgrowth of mouse blastocysts and receptivity of endometrial epithelial cells. Anim Reprod Sci 92: 155-167, 2006.

16. Alfer J, Muller-Schottle F, Classen-Linke I, et al: The endometrium as a novel target for leptin: differences in fertility and subfertility. Mol Hum Reprod 6: 595-601, 2000.

17. Koshiba H, Kitawaki J, Ishihara H, et al: Progesterone inhibition of functional leptin receptor mRNA expression in human endometrium. Mol Hum Reprod 7: 567-572, 2001.

18. Cervero A, Horcajadas JA, Martin J, et al: The leptin system during human endometrial receptivity and preimplantation development. J Clin Endocrinol Metab 89: 2442-2451, 2004.

19. Lima-Couy I, Cervero A, Bonilla-Musoles F, et al: Endometrial leptin and leptin receptor expression in women with severe/moderate endometriosis. Mol Hum Reprod 10: 777-782, 2004.

20. Ramos MP, Rueda BR, Leavis PC, et al: Leptin serves as an upstream activator of an obligatory signaling cascade in the embryo-implantation process. Endocrinology 146: 694-701, 2005.

21. Cioffi JA, Van Blerkom J, Antczak M et al: The expression of leptin and its receptors in pre-ovulatory human follicles. Mol Hum Reprod 3: 467-472, 1997.

22. Kim HS, Lee GS, Kim JH, et al: Expression of leptin ligand and receptor and effect of exogenous leptin supplement on in vitro development of porcine embryos. Theriogenology 65: 831-844, 2006.

23. Selam B, Kayisli UA, Mulayim N, et al: Regulation of Fas ligand expression by estradiol and progesterone in human endometrium. Biol Reprod 65: 979-985, 2001.

24. Song J, Rutherford T, Naftolin F, et al: Hormonal regulation of apoptosis and the Fas and Fas ligand system in human endometrial cells. Mol Hum Reprod 8: 447-455, 2002.

25. Abe H, Shibata MA and Otsuki Y: Caspase cascade of Fasmediated apoptosis in human normal endometrium and endometrial carcinoma cells. Mol Hum Reprod 12: 535-541, 2006.

26. Kamijo T, Rajabi MR, Mizunuma H, et al: Biochemical evidence for autocrine/paracrine regulation of apoptosis in cultured uterine epithelial cells during mouse embryo implantantion in vitro. Mol Hum Reprod 4: 990-993, 1998.

27. Galn A, O'Connor JE, Valbuena D, et al: The human blastocyst regulates endometrial epithelial apoptosis in embryonic adhesion. Biol Reprod 63: 430-439, 2000.

28. Tanaka $\mathrm{T}$ and Umesaki N: Cytokine regulation of apoptotic susceptibility in a human endometrial epithelial cell line. J Reprod Immunol 47: 105-119, 2000.

29. Atasoy P, Bozdoan O, Erekul S, et al: Fas-mediated pathway and apoptosis in normal, hyperplastic, and neoplastic endometrium. Gynecol Oncol 91: 309-317, 2003.

30. Tanaka T and Umesaki N: Fas antigen (CD95) mediates cell survival signals to regulate functional cellular subpopulations in normal human endometrial stromal cells. Int J Mol Med 11: 757-762, 2003.

31. Tanaka T, Utsunomiya T, Bai T, et al: Leptin inhibits decidualization and enhances cell viability of normal human endometrial stromal cells. Int J Mol Med 12: 95-98, 2003.

32. Ishiwata I, Ishiwata C, Soma M et al: Establishment of human endometrial adenocarcinoma cell line containing estradiol-17ß and progesterone. Gynecol Oncol 17: 281-290, 1984.

33. Mikami M, Sakai K, Yoshiki J, et al: Differentiation of endometrial carcinoma cell lines cultured in type 1 collagen gel and significance of sulfate lipid. Acta Obstet Gynecol Jpn 48: S348, 1996.

34. Yuan S, Tsai K, Chung Y, et al: Aberrant expression and possible involvement of the leptin receptor in endometrial cancer. Gynecol Oncol 92: 769-775, 2004.

35. Löffler S, Aust G, Köhler U, et al: Evidence of leptin expression in normal and polycystic human ovaries. Mol Hum Reprod 7: 1143-1149, 2001.

36. Matarese G, Alviggi C, Sanna V, et al: Increased leptin levels in serum and peritoneal fluid of patients with pelvic endometriosis. J Clin Endocrinol Metab 85: 2483-2487, 2000. 
37. Matalliotakis IM, Koumantaki YG, Neonaki MA, et al: Increase in serum leptin concentrations among women with endometriosis during danazol and leuprolide depot treatments. Am J Obstet Gynecol 183: 58-62, 2000 .

38. Gogacz M, Polak G, Jakowicki J, et al: Peritoneal fluid leptin concentration in infertile patients. J Reprod Immunol 51: 159-165, 2001.

39. Vigano P, Somigliana E, Matrone R, et al: Serum leptin concentrations in endometriosis. J Clin Endocrinol Metab 87: 1085-1087, 2002.

40. Mahutte NG, Matalliotakis IM, Goumenou AG, et al: Inverse correlation between peritoneal fluid leptin concentrations and the extent of endometriosis. Hum Reprod 18: 1205-1209, 2003.

41. De Placido G, Alviggi C, Carravetta C, et al: The peritoneal fluid concentration of leptin is increased in women with peritoneal but not ovarian endometriosis. Hum Reprod 16: 1251-1254, 2001

42. Bedaiwy MA, Falcone T, Goldberg JM, et al: Peritoneal fluid leptin is associated with chronic pelvic pain but not infertility in endometriosis patients. Hum Reprod 21: 788-791, 2006.

43. Della-Fera MA, Li C and Baile CA: Resistance to IP leptininduced adipose apoptosis caused by high-fat diet in mice. Biochem Biophys Res Commun 303: 1053-1057, 2003.

44. Gullicksen PS, Della-Fera MA and Baile CA: Leptin-induced adipose apoptosis: Implications for body weight regulation. Apoptosis 8: 327-335, 2003.

45. Della-Fera MA, Choi YH, Hartzell DL, et al: Sensitivity of $\mathrm{ob} / \mathrm{ob}$ mice to leptin-induced adipose tissue apoptosis. Obes Res 13: 1540-1547, 2005.

46. Utsumi H, Iwakiri R, Wu B, et al: Intracerebroventricular administration of leptin-induced apoptosis in the rat small intestinal mucosa. Exp Biol Med 228: 1239-1244, 2003.

47. Kim GS, Hong JS, Kim SW, et al: Leptin induces apoptosis via ERK/cPLA2/cytochrome c pathway in human bone marrow stromal cells. J Biol Chem 278: 21920-21929, 2003.

48. Almog B, Gold R, Tajima K, et al: Leptin attenuates follicular apoptosis and accelerates the onset of puberty in immature rats. Mol Cell Endocrinol 183: 179-191, 2001.

49. Hamm ML, Bhat GK, Thompson WE, et al: Folliculogenesis is impaired and granulosa cell apoptosis is increased in leptindeficient mice. Biol Reprod 71: 66-72, 2004.

50. Okuya S, Tanabe K, Tanizawa Y, et al: Leptin increases the viability of isolated rat pancreatic islets by suppressing apoptosis. Endocrinology 142: 4827-4830, 2001.

51. Fujita Y, Murakami M, Ogawa Y, et al: Leptin inhibits stressinduced apoptosis of T lymphocytes. Clin Exp Immunol 128: 21-26, 2002.
52. Papathanassoglou E, El-Haschimi K, Li XC, et al: Leptin receptor expression and signaling in lymphocytes: kinetics during lymphocyte activation, role in lymphocyte survival, and response to high fat diet in mice. J Immunol 176: 7745-7752, 2006.

53. Najib S and Sanchez-Margalet V: Human leptin promotes survival of human circulating blood monocytes prone to apoptosis by activation of p42/44 MAPK pathway. Cell Immunol 220: 143-149, 2002.

54. Bruno A, Conus S, Schmid I, et al: Apoptotic pathways are inhibited by leptin receptor activation in neutrophils. J Immunol 174: 8090-8096, 2005.

55. Conus S, Bruno A and Simon HU: Leptin is an eosinophil survival factor. J Allergy Clin Immunol 116: 1228-1234, 2005.

56. Mattioli B, Straface E, Quaranta MG, et al: Leptin promotes differentiation and survival of human dendritic cells and licenses them for Th1 priming. J Immunol 174: 6820-6828, 2005.

57. Russo VC, Metaxas S, Kobayashi K, et al: Antiapoptotic effects of leptin in human neuroblastoma cells. Endocrinology 145: 4103-4112, 2004

58. Ogunwobi O, Mutungi G and Beales IL: Leptin stimulates proliferation and inhibits apoptosis in Barbett's oesophageal adenocarcinoma cells by COX-2 dependent, PGE2 mediated transactivation of the EGF receptor and JNK activation. Endocrinology 147: 4505-4516, 2006.

59. Boelhauve M, Sinowatz F, Wolf E, et al: Maturation of bovine oocytes in the presence of leptin improves development and reduces apoptosis of in vitro-produced blastocysts. Biol Reprod 73: 737-744, 2005.

60. Fedorcsak P and Storeng R: Effects of leptin and leukemia inhibitory factor on preimplantation development and STAT3 signaling of mouse embryos in vitro. Biol Reprod 69: 1531-1538, 2003.

61. Rouet-Benzineb P, Aparicio T, Guilmeau S, et al: Leptin counteracts sodium butyrate-induced apoptosis in human colon cancer HT-29 cells via NF-kappaB signaling. J Biol Chem 279: 16495-16502, 2004

62. Gonzalez RR, Rueda BR, Ramos MP, et al: Leptin-induced increase in leukemia inhibitory factor and its receptor by human endometrium is partially mediated by interleukin 1 receptor signaling. Endocrinology 145: 3850-3857, 2004.

63. Nakajima S, Tanaka $\mathrm{T}$, Umesaki $\mathrm{N}$, et al: Leukemia inhibitory factor regulates cell survival of normal human endometrial stromal cells. Int J Mol Med 11: 353-356, 2003. 